\title{
BIRDS OF THE CRANE LAKE, SASKATCHEWAN AREA, 1983-1984
}

ANTHONY L. LANG, Department of Zoology, University of Toronto, Toro Ontario. M5S $1 \mathrm{~A} 1$

While employed as a summer field assistant for Ducks Unlimited Canada in 1983 and 1984, the author aided in research at various Ducks Unlimited projects in southern Saskatchewan and Alberta. A great deal of time was spent at Crane Lake, Saskatchewan, a large marsh which lies northeast of Piapot and just north of the Trans-Canada Highway. In the past, Crane Lake was noted for its abundance of birds, especially waterfowl. ${ }^{238}$ Water levels have ranged from a permanent, large, shallow lake 1-3 m deep to being completely dry in several years, due to low levels of spring runoff and precipitation, high rates of evaporation, and irrigation from the Bear and Piapot creeks flowing into the southern side of the lake. ${ }^{4}$

In the recent past Crane Lake has been a shallow marsh less than $1 \mathrm{~m}$ deep but dry by the fall. In the fall of 1981, however, Ducks Unlimited Canada began construction on dykes to contain the remaining water in a smaller, deeper area in order to reduce evaporation and to provide high enough water levels to support emergent aquatic vegetation. A dyke of approximately $17 \mathrm{~km}$ in circumference ringing a central area of clay in the lake basin, with wing dykes extending along the delta of Piapot Creek, was completed in the fall of 1981. Approximately 40 artificial islands were constructed at this time. The dyke encloses a basin of 1,140 ha (Ducks Unlimited Completed Project Sheet).

The basin of Crane Lake covers much of Township 13, Range 23, West of the 3rd Meridian. It is the terminal basin for Piapot Creek and local inflow, and lies on the southern edge of the Great Sand I The vegetation surrounding the enclosed by the dyke consists primari native grassland in the lake basin (inc ing large areas of Foxtail Barley, Hord jubatum) and grassland and o shrubland in the stabilized sand $d u$ that surround much of the basin.

The vegetation within the dyke du 1983 and 1984 consisted primarily of communities: one of Prairie Bulrush (. pus paludosus) and another of Great rush (S. acutus). Within each commi the other species of bulrush was pre as were Common Cattail (Typha latifd Saline Bulrush ( $S$. nevadensis), Spikerush (Eleocharis palustris). In summer of 1984 Foxtail Barley bega invade the prairie bulrush commu The area within the dyke was al completely overgrown with emer vegetation in both years except ditches along the entire length of dykes and the moats surrounding th tificial islands.

In 1983 water levels in the Prairie rush community ranged from proximately $30 \mathrm{~cm}$ in May to $0-5 \mathrm{c}$ August. In the Great Bulrush comm water levels ranged from $70 \mathrm{~cm}$ in $M$ approximately $40 \mathrm{~cm}$ in August. moats and ditches held water to a n mum depth of $1.5 \mathrm{~m}$. Little snow fe the area during the winter of 1983-84 rainfall during the spring of 1984 below normal. As a result, water leve May of 1984 were virtually uncha from the previous August. By the fo week of July water remained only in s of the island moats. 
The bird observations on some 61 cies presented here were made inentally during the course of breeding ck pair counts, duckling brood counts, getation transects, aerial duck counts, inest searches of artificial islands from $y$ to August. The marsh was visited for lays on average approximately every days in 1983, and was visited for 2 s every 7 days in 1984 until 18 July. st of the observations were made from ring dyke around the marsh and from dykes along Piapot Creek leading into south side of the marsh. As a result do not provide a complete picture of number of bird species and induals that may have been within the sh. In addition, difficult shorebird era were not always identified down pecies. Except where noted, the obations were made by the author.

rms of abundance were used in a ner similar to Belcher, but were used for the average abundance (not denduring the observation period, for breeding and nonbreeding species observed.' The terms are defined as follows:

abundant - more than 500 individuals seen or heard in a single day.

very common - 101-500 in a single day

common - 26-100 seen in one day

fairly common - 6-25 seen in one day

uncommon - 1-5 observed in a single day, no more than 25 per season

rare - $1-5$ in a single day, no more than 5 seen or heard per season

very rare - no more than 1 observed per season

EARED GREBE Fairly common. On 5 June 1983 a nesting colony was located in the Prairie Bulrush community near a Franklin's Gull colony. There were at least 25 Eared Grebe nests. Young were seen later in the nesting season. Epp

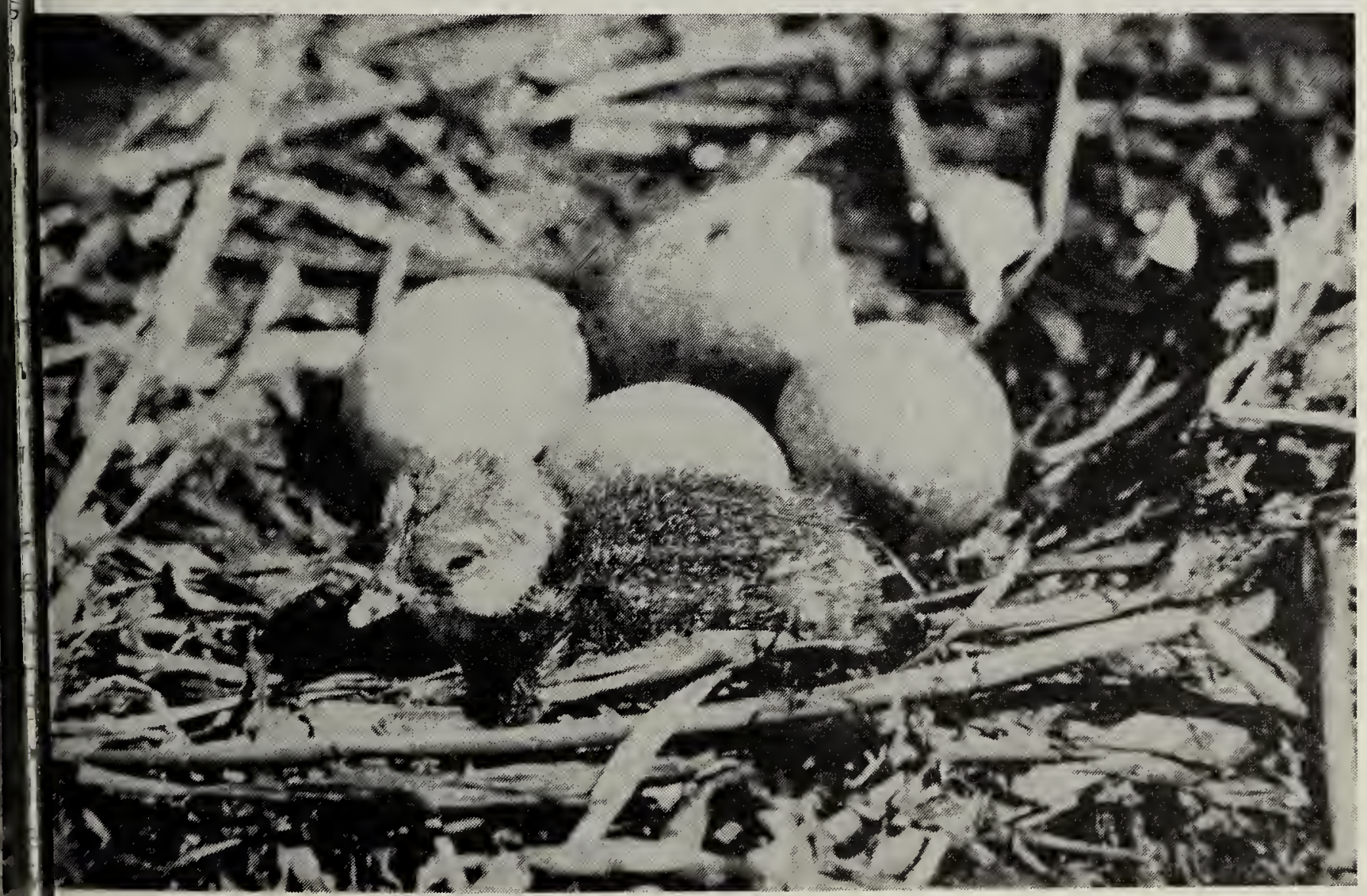

Grebe young and eggs in nest

R.E.Gehlert 
and Waker saw an adult with young at Crane Lake in $1978 .^{5}$

AMERICAN WHITE PELICAN Uncommon. Three pelicans were observed soaring over the marsh on 15 August 1983. One pelican was seen standing in open water a few cm deep in the center of the marsh on 26 June 1984. A group of 19 was seen on 18 July 1984 in some of the only open water, which was located at the very eastern end of the marsh in the inner ditch between the marsh and the dyke. Pelicans nested at Crane Lake in the past, although no individuals were observed by Epp and Waker in 1978.?

AMERICAN BITTERN Uncommon. Adults were flushed occasionally and heard calling in the spring. A large, downy nestling, but no nest, was found on 29 July 1983 . On 15 June 1984 an adult was heard calling.
GREAT BLUE HERON Uncommo 1983 adults were seen regularly i ditches in July and August. On 28 1984 two groups of two were ser the outer ditches.

SNOWY EGRET Very rare. On 15 1984 an individual in flight crosse dyke near the mouth of Piapot C The neck was held in a tight curve the bird was approximately the si nearby Black-crowned Night-He The black legs and contrasting ye feet were clearly visible through binoculars at a distance of $30 \mathrm{~m}$. may be the same bird as that see 23 and 24 June 1984 at Old Wives by other observers. ${ }^{6}$

BLACK-CROWNED NIGHT-HER Fairly common. In 1983 many a were seen in May. On 5 June 19 nesting colony with an estimated mum of 20 nests was found wit

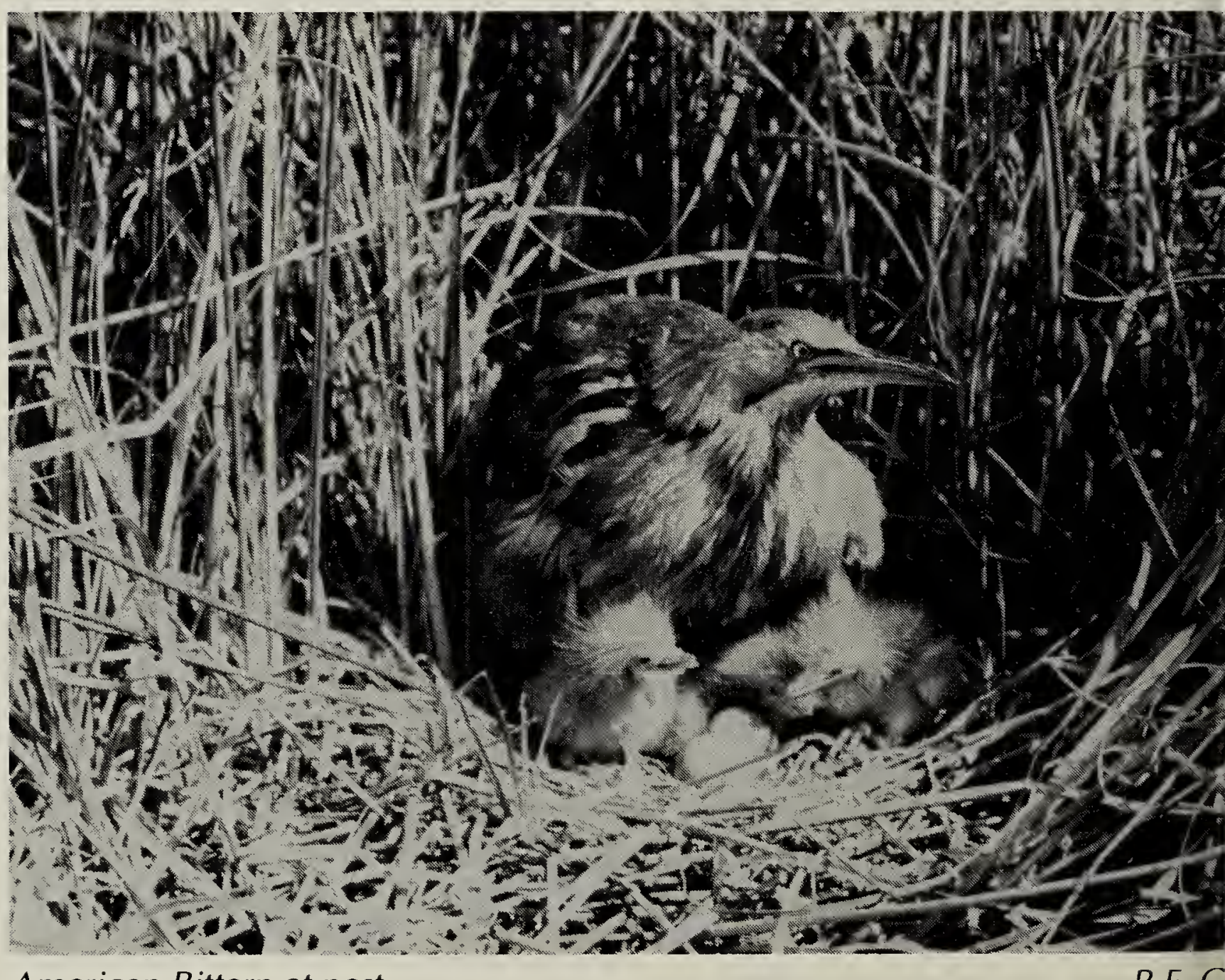

American Bittern at nest 
anklin's Gull colony in the Great Bulsh community. Nests were conructed of Great Bulrush stems and chored to the bulrushes at the water he. Young were photographed in the est on 5 July 1983 by Thomasz nkowsky. Many fledged juveniles ere seen later in the summer. Small mbers of adults were noted on 7 May d 18 May 1984; on 26 June 1984 ge young were found in nests in the lony.

DRA SWAN Rare from May to gust. One bird was seen on 5 and 6 y 1983 in the deeper water at the tt end of the marsh. Thomasz kowsky observed a flock of apximately 120 on 13 October 1983.

W GOOSE Uncommon. Six were on 7 May 1984.

ADA GOOSE Common. Many ed on flax bales placed in the marsh on the artificial islands; many ds were seen in both years.

-WINGED TEAL This species fairly common in the breeding on but groups of summering males seen on 19 June 1983. They were common in the flocks of reeding ducks seen in July and ist of 1983. A few broods were rved.

ARD Very common throughout bservation period. Many broods seen. Large postbreeding flocks the outer ditches in July and st of 1983.

HERN PINTAIL Very common hout the period. Many broods seen. Large postbreeding flocks seen in July and August of 1983, ially on 12 August when several flocks consisting of hundreds of were observed.
BLUE-WINGED TEAL Very common. Many broods were observed. Seen in flocks in July 1983.

CINNAMON TEAL Uncommon. Two pairs were seen on 22 May 1983 in the ditch next to the dyke. On 4 June 1983 two males were seen in the ditch. One pair and one male were seen in the outer ditch west of the mouth of Piapot Creek on 19 May 1984. On 5 June 1984 one male was seen in the ditch and on 18 June 1984 one pair was seen in the north-central portion of the marsh. Apparent Blue-winged Teal broods were not examined closely to determine whether any of the hens were Cinnamon Teals. Bent saw one on 17 June 1905 at Crane Lake. ${ }^{2}$

NORTHERN SHOVELER Very common. One of the most numerous ducks in the ditches during the breeding season. Many broods were observed. On 18 May 1984 an albino shoveler flushed up with a male from the northeast part of the marsh. The male stayed close to the albino as if it were its mate. On 20 May 1984 the pair was flushed from the same spot and again the male stayed close to the albino. Based on these observations I concluded the albino was a female.

GADWALL Very common. Large numbers of paired birds were counted in late May and early June. Many broods were observed.

AMERICAN WIGEON Very common. Almost as common as the Mallard. Many broods were observed and flocks of postbreeding birds were seen on 12 August 1983.

CANVASBACK Fairly common. A few broods were seen.

REDHEAD Very common. The most numerous duck within the vegetated 
basin enclosed by the dyke. Several broods were seen.

RING-NECKED DUCK Very rare. One male was seen on 19 May 1984.

LESSER SCAUP Common. The most numerous diver in the ditches (which contained much of the deeper water in the marsh). Many broods were seen.

BUFFLEHEAD Uncommon. One pair was seen 5 May 1983. Three pairs and two males were seen on 22 May 1983. One male and a separate female were seen 4 June 1983. One pair was seen 19 June 1983 and on 6 July 1983 a first year male was seen. Six adults were seen on 16 June 1984.

RED-BREASTED MERGANSER Rare. One pair was seen in the ditch west of the mouth of Piapot Creek on 8 May 1984.

RUDDY DUCK A common breeder. Many broods were observed.
NORTHERN HARRIER Fairly comm Seen frequently throughout the per

SWAINSON'S HAWK Uncomm Seen frequently in the area around marsh. On 11 August 1983 one flushed from the dyke with American Coot in its talons. On 81 1984 one was observed south of marsh near the Trans-Canada High diving at a Ferruginous Hawk wl was on the ground. These observat were made in passing; subsequent haviour was not observed.

One was flushed from the dyke or May 1984 carrying a coot. On 19 1984 two were observed diving flying Ferruginous Hawk which flown near the pair's nest located tree about $1 \mathrm{~km}$ south of the marst

RED-TAILED HAWK Very rare. One seen flying over a stand of Tremb Aspen about $1 \mathrm{~km}$ north of the $\mathrm{m}$ on 15 July 1983.

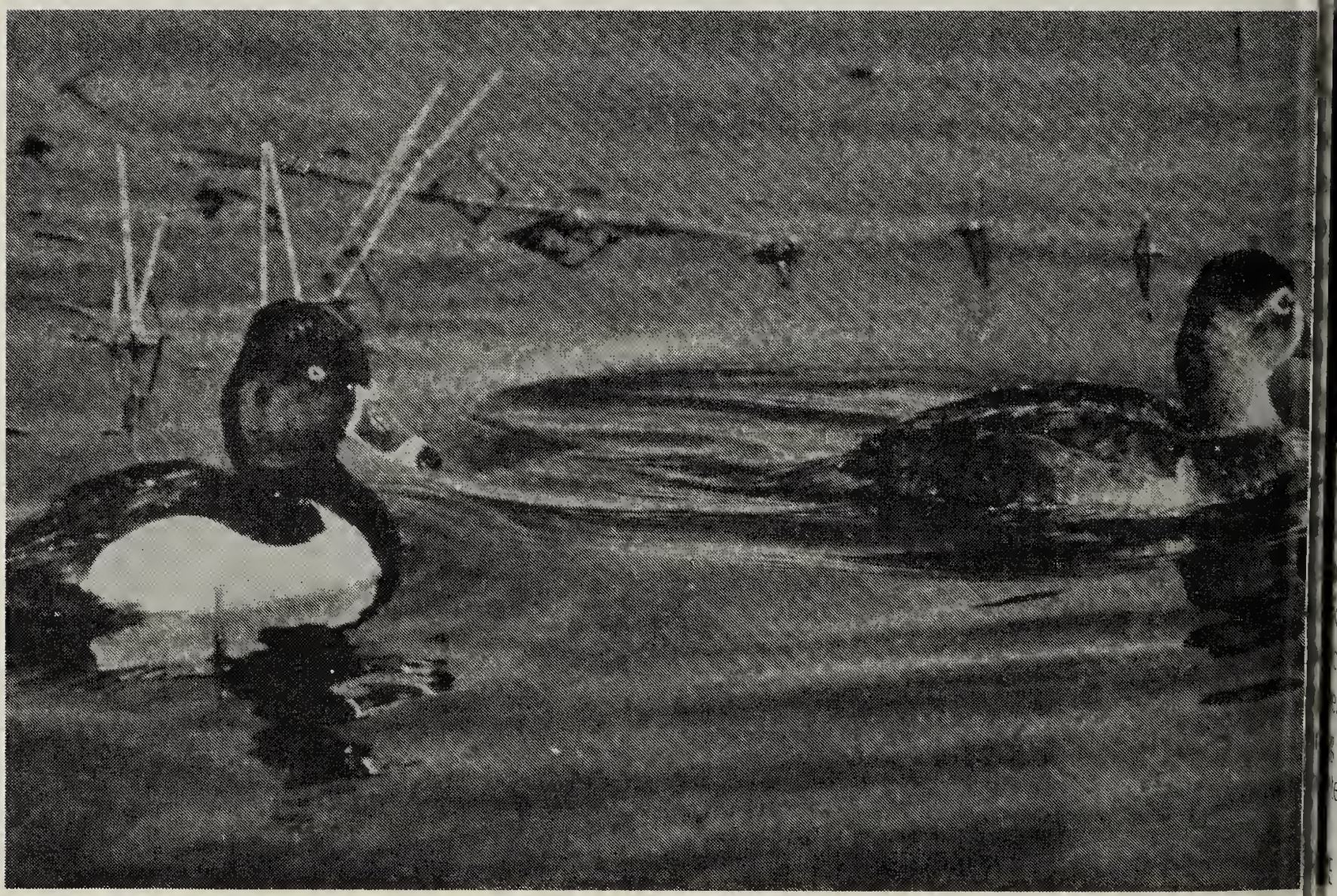


RRUGINOUS HAWK Uncommon. fingle birds were seen south of the narsh on 22 May, 15 July, and 15 fugust 1983 and 7, 8, and 19 May and June 1984. Interactions with wainson's Hawks were observed (see wainson's Hawk).

RLIN Very rare. A female or immaire was seen on a fence about $1 \mathrm{~km}$ puth of the marsh on 15 August 1983.

\section{EGRINE FALCON Very rare. On 7} lay 1984 a Peregrine was seen in the orning about $0.5 \mathrm{~km}$ south of the arsh along Piapot Creek. It flew to a nce on the dyke along the south side the marsh, east of the mouth of Piapot reek. In mid-afternoon, it was seen ing rapidly southwards at an altitude 1-2 $\mathrm{m}$ over the ditch along the dyke rdering the east side of Piapot Creek. orebirds and ducks were flushing as falcon flew along until it made a dden stoop and struck a female teal ich had fluttered up the side of the ke. The falcon executed a near vertiloop of about $2 \mathrm{~m}$ in diameter, and ick the duck again while it was still the dyke, causing the duck to flutter $w n$ the dyke almost to the water line. falcon gained some altitude, struck duck again, hovered momentarily, 1 landed on it. By this time the truck taining the author and Thomasz kowsky had been stopped and the on was observed from a distance of $\mathrm{m}$ with binoculars and a $25 \mathrm{X}$ spotscope. The falcon plucked the $k$ and fed on it for 10 minutes. We drove closer to try to determine the cies of prey but the falcon flew 50 outh down the dyke carrying the $k$. When the falcon was apched again, it flew 50 m eastward, endicular to the path of the truck $g$ the dyke. Observations were terated at this time.

IE FALCON Rare. On 14 August one was seen chasing a duck but when the duck hit the water, the falcon broke off the chase. Later the same day a Prairie Falcon was flushed from the dyke with a coot in its talons (possibly the same bird). One was seen the next day south of the marsh. On 21 May 1984 one was seen at the east end of the marsh.

SHARP-TAILED GROUSE Fairly common. A group was flushed from a dancing ground in the sandhills south of the marsh on 4 May 1983. Individuals were seen later in this area. On 10 June 1984 , three were flushed from the same location.

AMERICAN COOT A very common breeder. Many nests were found and later, many young were seen.

BLACK-BELLIED PLOVER Uncommon. Three were seen in one spot in the outer ditch around the marsh dyke on 4 June 1983. On 19 May 1984, two small groups were seen.

KILLDEER Common along the dyke around the marsh. This species likely nested on the dyke.

AMERICAN AVOCET Common along the dyke, on which it likely nested. On 7 May 1984 a group of 15 was seen feeding together.

YELLOWLEGS Spp. Fairly common. In 1983 both species were seen at the marsh from mid-July onwards. On 7 May 1984 unidentified yellowlegs were noted. Small flocks of Greater Yellowlegs were seen around the marsh on 26 June 1984.

WILLET Common along the dyke where it likely nested.

UPLAND SANDPIPER Uncommon. Two were seen near the Trans-Canada Highway about $7 \mathrm{~km}$ south of the marsh on 13 May 1984. One was seen on 19 
May 1984 along the dyke bordering the south side of the marsh. Four were seen on 4 June 1984 on the dyke on the northern side of the marsh.

LONG-BILLED CURLEW Very rare. One was seen on the dyke on the north side of the marsh on 4 June 1984 .

MARBLED GODWIT Common on the dyke, where it likely nested.

PEEPS (CALIDRIS) Spp. Very common in migration. In August of 1983 peeps were noted at the marsh. On 18 May 1984 many were seen around the marsh.

DOWITCHER Spp. Common in migration. On 7 and 8 May 1984 a flock was noted in the outer ditch. On 19 May 1984 two small groups were seen and on 11 July 1984 several small flocks were seen around the marsh.

COMMONSNIPE Rare. On 5 June 1984 one was seen in courtship flight ("winnowing"). On 15 June 1984 one was heard winnowing.
WILSON'S PHALAROPE COMr around the marsh. On 2 June 1983 were observed copulating. This spe also likely nested here, based on occurrence of distraction disp given by adult males.

FRANKLIN'S GULL Abundant. C June 1983 a colony estimated to clude approximately 400 pairs wa: countered in dense stands of $C$ Bulrush in the east-central portio the marsh. The nests contained eg, young. Later in the summer large lings were found and fledged yc were seen. On 19 May 1984 nests found with none to two eggs and o June 1984 large nestlings were $n$ Bent found three small colonit Crane Lake in $1906 .{ }^{\prime}$

RING-BILLED GULL Fairly comr This species was seen regularly are the marsh but no nests were founc

HERRING GULL Very rare. On 13 tober 1983 Thomasz Sankowsky one at the marsh.

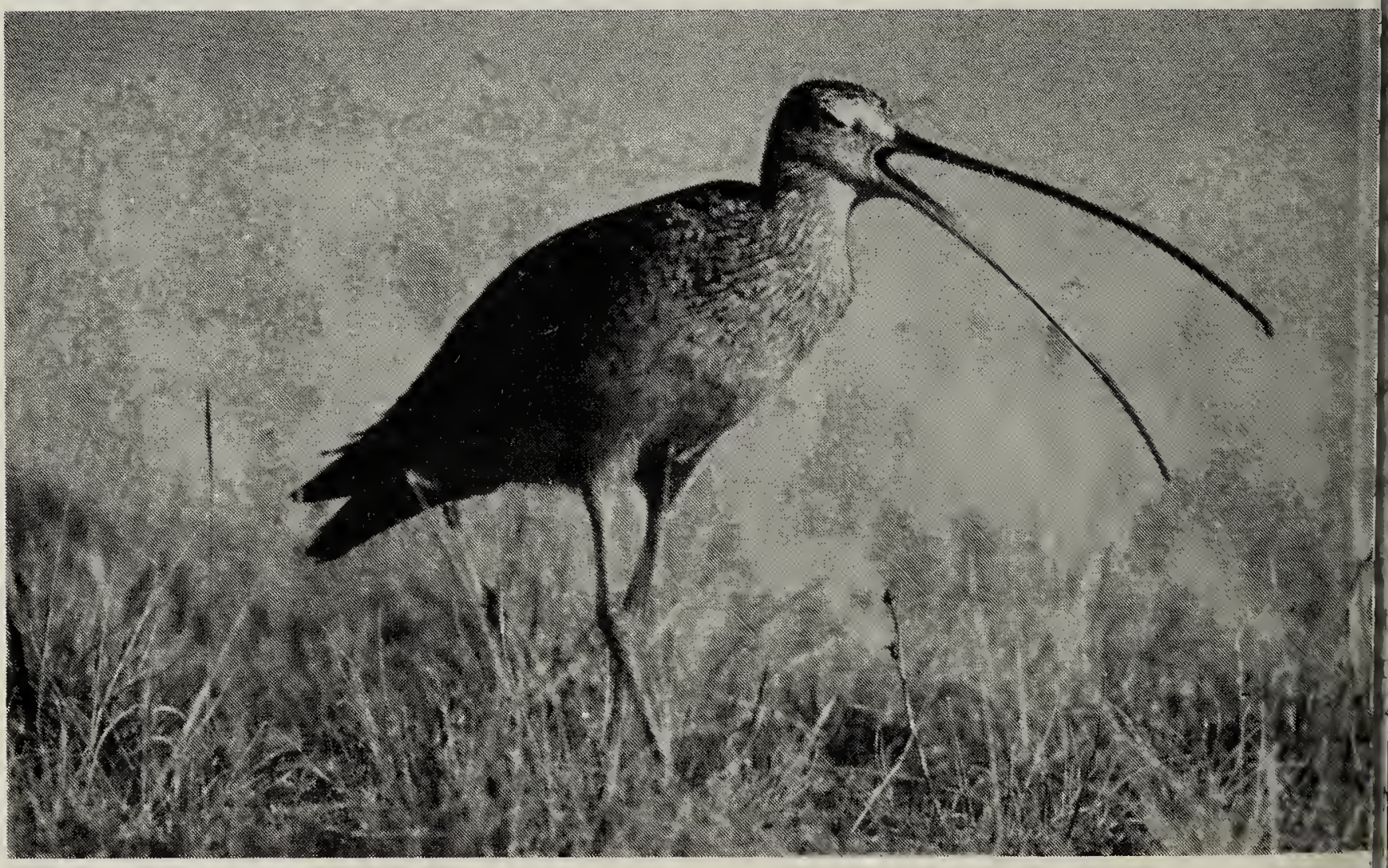


RSTER'S TERN Rare. On 21 May 1984, two were seen and heard flying ow over the center of the marsh.

ACK TERN Fairly common at the harsh. Several nests with eggs were bund.

EAT HORNED OWL Very rare. One as seen on the dyke on 8 September 983 by Thomasz Sankowsky.

RROWING OWL Very rare. On 5 ay 1983 one was seen between the arsh and the sand hills, about $5 \mathrm{~km}$ uth of the marsh.

RRT-EARED OWL Very rare. On ening of 10 June 1984 one was seen out $1 \mathrm{~km}$ south of the marsh diving a while at two coyotes which were out $15 \mathrm{~m}$ apart.

SH WREN Fairly common. In the ing of 1983 this species was heard ging frequently in Great Bulrush ids. A few unoccupied ("dummy"?) ts were found. On 19 May 1984 ing birds were noted.

GUE'S PIPIT Fairly common. This cies was often heard singing south he marsh.

MON YELLOWTHROAT VEY . On 5 June 1984 one was singing he marsh.

E SPARROW Fairly common. species was heard singing fretly south of the marsh.

BUNTING Rare. Four were seen of the marsh at the edge of the hills on 2 June 1983. On 4 June , one was seen in the same area.

INAH SPARROW Fairly comThis species was often heard singputh of the marsh.
YELLOW-HEADED BLACKBIRD Very common. Many nests of this species with eggs and young were found in both years. Small groups were often seen feeding on the dyke.

\section{Acknowledgements}

I would like to thank Thomasz Sankowsky of Ducks Unlimited Canada for his additional bird observations and for his tolerance of my interest in the birds of Crane Lake. I would also like to thank Shirley Rushforth Guinn, also of Ducks Unlimited Canada, for permission to use observations of duck numbers in this note.

1 BELCHER, M. 1980. Birds of Regina, revised ed. Special Publ. No. 12, Sask. Natural History Society, Regina.

2 BENT, A.C. 1907. Summer birds of southwestern Saskatchewan. Auk 24:407430.

${ }^{3}$ BENT, A.C. 1908. Summer birds of southwestern Saskatchewan. Auk 25:2535.

${ }^{4}$ ENVIRONMENTAL MANAGEMENT ASSOCIATES 1981. Environmental impact statement, Crane Lake development, Saskatchewan. Prepared for Ducks Unlimited (Canada) by Environmental Management Associates, Calgary.

${ }^{5}$ EPP, H.T. and B.D. WAKER 1980 . Terrestrial vertebrate fauna of the Great Sand Hills: pp. 75-89 in: H.T. EPP and L. TOWNLEY-SMITH (Eds.). The Great Sand Hills of Saskatchewan. Sask. Dept. of the Environment: Policy, Planning And Research Dept. 156 pp.

${ }^{6}$ GOLLOP, J.B. 1984. Prairie Provinces region, nesting season: June 1-July 31, 1984. Am. Birds 38(6):1031-1033.

7 HOUSTON, C.S. 1962. Hazards faced by colonial birds. Blue Jay 20:74-77.

${ }^{8}$ HOUSTON, C.S. 1983 . Birds and birders at Crane Lake, Saskatchewan. Blue Jay 41:194-199. 